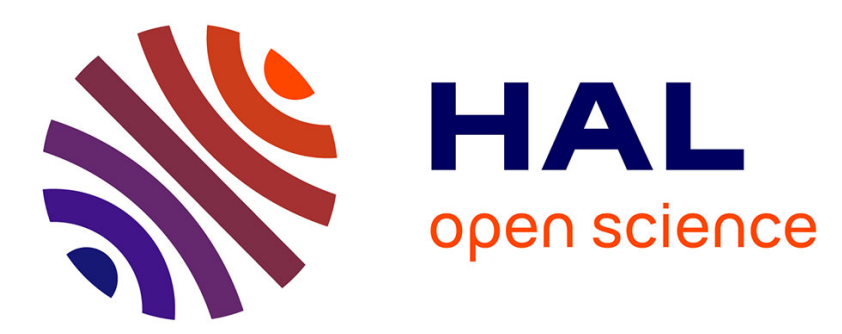

\title{
Runoff and precipitation dynamics in the Blue and White Nile catchments during the mid-Holocene: A data-model comparison
}

\author{
C L Blanchet, C Contoux, G L Leduc
}

\section{- To cite this version:}

C L Blanchet, C Contoux, G L Leduc. Runoff and precipitation dynamics in the Blue and White Nile catchments during the mid-Holocene: A data-model comparison. Quaternary Science Reviews, 2015, 130, pp.222 - 230. 10.1016/j.quascirev.2015.07.014 . hal-01457237

\section{HAL Id: hal-01457237 \\ https://hal-amu.archives-ouvertes.fr/hal-01457237}

Submitted on 20 Feb 2017

HAL is a multi-disciplinary open access archive for the deposit and dissemination of scientific research documents, whether they are published or not. The documents may come from teaching and research institutions in France or abroad, or from public or private research centers.
L'archive ouverte pluridisciplinaire HAL, est destinée au dépôt et à la diffusion de documents scientifiques de niveau recherche, publiés ou non, émanant des établissements d'enseignement et de recherche français ou étrangers, des laboratoires publics ou privés. 


\title{
Runoff and precipitation dynamics in the Blue and White Nile catchments during the mid-Holocene: A data-model comparison
}

\author{
C.L. Blanchet ${ }^{\text {a, b, }}{ }^{*}$, C. Contoux ${ }^{c}$, G. Leduc ${ }^{c}$ \\ ${ }^{a}$ GEOMAR Helmholtz Centre for Ocean Research Kiel, Kiel, Germany \\ b NIOZ Royal Netherlands Institute for Sea Research, Texel, The Netherlands \\ ' Aix-Marseille Université, CNRS, IRD, CEREGE UM34, 13545 Aix en Provence, France
}

\section{A R T I C L E I N F O}

\section{Article history:}

Received 7 February 2015

Received in revised form

22 May 2015

Accepted 13 July 2015

Available online 26 July 2015

\section{Keywords:}

Nile River

Mid-Holocene

Palaeo-humidity

Blue Nile

White Nile

Seasonality

\begin{abstract}
A B S T R A C T
The Blue Nile is the major contributor of freshwater and sediments to the modern-day main Nile River and exerts a key control on seasonal flooding in the Nile valley. Recent studies have postulated that the relative contribution from the Blue Nile to the main Nile runoff might have been reduced during the midHolocene, at a time when higher boreal summer insolation stimulated enhanced precipitation in North Africa. Whether the decrease in the relative contribution from the Blue Nile resulted from a decrease in precipitation over the catchment, from an increase in White Nile runoff or from a combination of both is still a matter of debate. By comparing regional proxy-records with the output from a global atmospheric model zoomed on Africa, we propose that the reduced contribution from the Blue Nile at 6 ka originated from both a higher White Nile runoff and a lower Blue Nile runoff. Enhanced African and Indian monsoons at 6 ka induced a northern shift of the Intertropical Convergence Zone and an eastward shift of the Congo Air Boundary. Such an atmospheric configuration led to a negative anomaly of summer precipitation over the Blue Nile catchment that likely resulted in a reduction in the Blue Nile runoff. By contrast, a sustained positive anomaly of precipitation over the White Nile catchment during both summer and autumn most likely induced a higher main Nile runoff during the mid-Holocene. Using the model output, we propose a first synoptic view on regional rainfall dynamics that permits to reconcile contrasting proxy records.
\end{abstract}

๑ 2015 Elsevier Ltd. All rights reserved.

\section{Introduction}

During the Holocene (i.e., the past 10 thousand years), the meridional migrations of the rainfall belt in the African subtropics lead to severe transformations of the climate and vegetation in this region (Gasse, 2000). After an arid interval during the Younger Dryas (ca. 12.5-11.5 ka), the northward migration of the rainfall belt allowed the development of savannah in parts of the Sahara Desert presently barren of any vegetation (Jolly et al., 1998). This greening of the Sahara occurred during the so-called African Humid Period (thereafter referred to as AHP), which lasted until the midHolocene, i.e. 6000 years ago (6 ka) (Kuper and Kröpelin, 2006). The abundance of resources allowed herds of big game to thrive in the Sahara, which were used by hunter-gatherer populations for their subsistence (Drake et al., 2011).

\footnotetext{
* Corresponding author. GEOMAR Helmholtz Centre for Ocean Research Kiel, Kiel, Germany.

E-mail address: cecile.blanchet@posteo.de (C.L. Blanchet).
}

After the mid-Holocene, the southward retreat of the rainfall belt provoked the disappearance of the vegetal and animal populations in the Sahara. It is also during this period (and perhaps during the AHP termination) that the transition between gathering and herding (pastoralism) occurred in northern Africa (Blanchet et al., 2014). In northern Sudan within the modern desert Nile, archaeological evidences faithfully track the progressive aridification of a series of secondary Nile channels from the early Holocene to the end of the AHP that were all active and allowed seasonal cultivation during the Neolithic period (Macklin et al., 2013). Such environmental and societal disruptions resulted in large-scale human migrations towards the banks of the Nile River, contributing to the rise of Pharaonic dynasties (Kuper and Kröpelin, 2006; Macklin et al., 2013; Macklin and Lewin, 2015). The AHP is therefore a key period in Earth's history to investigate the connexions between climatic changes and human societies dynamics.

Changes in boreal summer insolation exerted a major control on climatic conditions in northern Africa during the mid-Holocene by reducing latitudinal temperature gradients (e.g. Braconnot et al., 
2007; Davis and Brewer, 2009; Bosmans et al., 2012). However, the geological record of environmental changes across Northeastern Africa is very heterogeneous, with large spatial and temporal offsets. Some records depict a progressive humid/arid transition following the changes in insolation (Fleitmann et al., 2003; Jung et al., 2004; Kröpelin et al., 2008; Weldeab et al., 2014), while other records point to a more rapid transition (Liu et al., 2007; Garcin et al., 2012; Tierney and deMenocal, 2013). Additionally, the humid/arid transition is not recorded synchronously over NE Africa, and is reported between $8.5 \mathrm{ka}$ (Blanchet et al., 2013, 2014; Costa et al., 2014) and 5.5 ka (Garcin et al., 2012; Tierney and deMenocal, 2013). This large temporal variability might result from regional climatic processes or variation in the time resolution of palaeoclimatic archive (Tierney and deMenocal, 2013), or from climate-environment feedback processes (Claussen et al., 1999). Temporal offsets might also result from a time-trangressive retreat of the African monsoon following the gradual decline in insolation forcing, with equatorial latitudes becoming arid later than tropical latitudes (Shanahan et al., 2015).

In the Nile River catchment, the changes in humidity and palaeoenvironments also reveal a complex pattern (Blanchet et al., 2014). Today, the two main branches of the Nile River provide contrasting contributions to the main Nile flow. The Blue Nile and Atbara rivers are the main contributors and flow mostly during the boreal summer, while the White Nile provides a more constant input throughout the year and becomes a significant contributor during the drier months (see e.g. Woodward et al., 2007 for an extensive review). Over the course of the Holocene, the overall Nile runoff decreased steadily, following the reduction in the summer insolation and southward migration of the rainfall belt (Revel et al., 2010; Marriner et al., 2012). By contrast, the reconstructions of past changes in the relative contribution from both sources to the main Nile runoff exhibit large and sometimes rapid variations during the Holocene (Krom et al., 2002; Box et al., 2011; Blanchet et al., 2013; Flaux et al., 2013; Véron et al., 2013). Several hypotheses have been proposed to account for the changes in source contribution to the main Nile runoff: i) a shift in the seasonal distribution of precipitation towards the autumn equinox, favouring a stronger White Nile runoff (Blanchet et al., 2013), and ii) the development of an extensive vegetation cover on the Ethiopian Highlands that prevented erosion and lead to a lower Blue Nile runoff (with precipitation remaining high, e.g. Krom et al., 2002).

Here, we aim at investigating the precipitation dynamics during the mid-Holocene in order to better understand the processes influencing the runoff dynamics in the Nile River catchment. First, we review available datasets of past humidity conditions from NE Africa in order to explore the potential forcing mechanisms and provide a synoptic picture of past humidity conditions in the region. This data-compilation is then compared to a simulation of mid-Holocene precipitation dynamics obtained using the LMDZ4 global atmospheric model (Contoux et al., 2013). This model has a zooming ability, which allows providing climatic variables for the preindustrial and the mid-Holocene at high-resolution above northern Africa, and therefore permits an investigation of the climatic processes influencing the precipitation dynamics in NE Africa.

\section{Present-day climatic conditions}

The annual rainfall dynamics above tropical Africa closely follow that of the insolation, with the northern tropics receiving rainfall during the boreal summer. Due to their latitudinal distribution and to local conditions, the sources of the Nile River have distinctive rainfall patterns: the Ethiopian Highlands (source of the Blue Nile and the Atbara River) receive large monsoonal rainfall during the boreal summer, while the Great Lakes region (source of the White Nile) has two rainfall peaks during the equinoxes, due to the biannual passage of the Intertropical Convergence Zone (ITCZ) over the area (Fig. 1). Williams et al. (1982) estimate that about two thirds of the main Nile mean annual discharge is inherited from the seasonal rains over the Ethiopian Highlands.

In the Ethiopian Highlands, the orography plays a crucial role in controlling the boreal summer rainfall. The main moisture sources are the eastern Mediterranean Sea (contributing for more than half of the moisture transported towards the Ethiopian Highlands), the Indian Ocean and the Atlantic Ocean (Fig. 1) (Viste and Sorteberg, 2013). About two thirds of the moisture released above the Ethiopian Highlands enter the region through the northeastern flanks of the Highlands. Convergence of moisture-laden winds coming from the Mozambique channel, and to a lesser extent from the eastern equatorial Atlantic, curl West and North of the orographic barrier represented by the Ethiopian Highlands, merge with moistureladen winds originating from the eastern Mediterranean sea before converging towards the highland into a cyclonic-type circulation, locally constrained by orography (Viste and Sorteberg, 2013). The resulting precipitation rates above the Ethiopian Highlands are highly seasonal, and about an order of magnitude higher than at similar latitudes further to the West above the White Nile catchment. The importance of orography on precipitation rates above the Ethiopian Highlands is further highlighted using modelling studies of the Mio-Pliocene moisture transport into this region (Sepulchre et al., 2006). Removing the East African Rift and the associated Ethiopian orography induces a mostly zonal moisture transport during boreal summer, with an increased contribution from the Atlantic Ocean and a reduced contribution from the Indian Ocean to the Ethiopian highland summer rainfall.

At the source of the White Nile, high precipitation rates occur all year long, with two distinctive rainfall peaks at the equinoxes (Fig. 1). However, the seasonality of the White Nile flow is modulated by storage in lakes and swamps, notably in the Sudd region in South Soudan (Woodward et al., 2007). The Sudd region acts as a sediment trap where most of the sediment loaded upstream deposits in swamps; the White Nile can loose up to $50 \%$ of its water through evaporation in these swamps (Howell et al., 1988).

\section{Material and methods}

\subsection{Proxy-data}

We use ten datasets obtained from both marine and continental archives analysed using various geochemical and sedimentological proxies (Table 1 \& Fig. 2a). Put together, these records provide a comprehensive picture of the spatial and temporal variations in palaeo-humidity during the Holocene in Northeastern Africa.

We use two records from the Mediterranean Sea. The first one is a sedimentary sequence collected from the Nile deep-sea fan, which was analysed using grain-size and radiogenic neodymium (Nd) and strontium (Sr) isotopes (resp., $\varepsilon N d$ and ${ }^{87} \mathrm{Sr} /{ }^{86} \mathrm{Sr}$ ) measurements, which allow tracking past changes in river runoff and fluvial sediment source (Blanchet et al., 2013). The second core was retrieved in the Levantine basin and was analysed using ${ }^{87} \mathrm{Sr} /{ }^{86} \mathrm{Sr}$ measurements to track the changes in fluvial sediment source (Box et al., 2011). The source rocks in the Blue and White Niles catchment areas have very different radiogenic isotope signatures (Padoan et al., 2011), which can be used to estimate the relative contributions from both sources to the main sediment flux. Although being slightly more radiogenic, the sediments originating from the source of the Atbara River cannot be distinguished from those originating from the Blue Nile (Padoan et al., 2011). At present, the seasonal pattern of contributions from the Atbara and the 

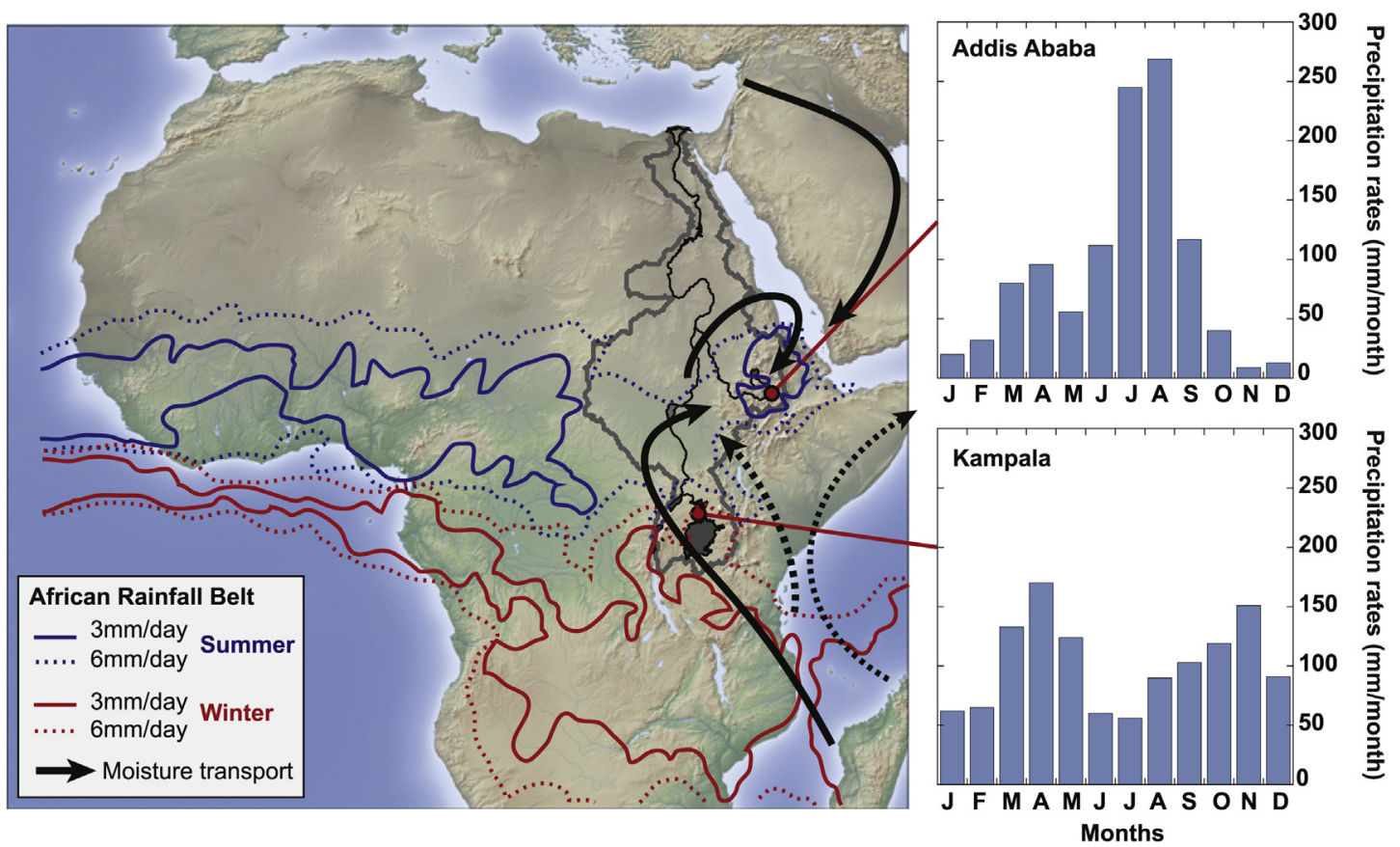

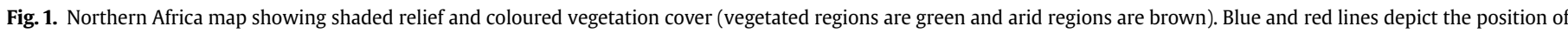

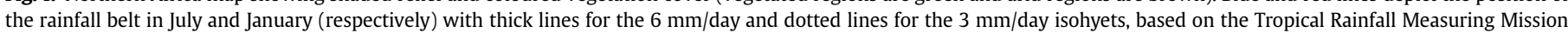

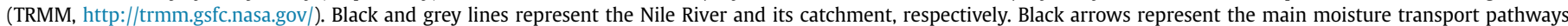

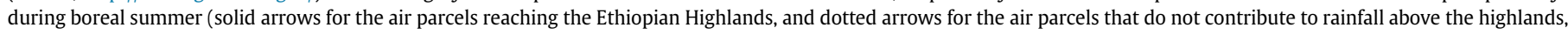

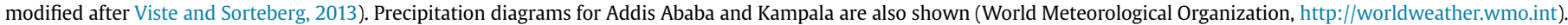
(For interpretation of the references to colour in this figure legend, the reader is referred to the web version of this article.)

Table 1

Records used for the data compilation.

\begin{tabular}{|c|c|c|c|}
\hline & Location & Proxy & Reference \\
\hline 1 & Nile deep-sea fan & Grain-size fractions & Blanchet et al. (2013) \\
\hline 2 & Nile Delta & Sedimentation rates & Marriner et al. (2012) \\
\hline 3 & Levantine Basin & ${ }^{87} \mathrm{Sr} /{ }^{86} \mathrm{Sr}$ & Box et al. (2011) \\
\hline 4 & Red Sea & Salinity & Arz et al. (2003) \\
\hline 5 & Horn of Africa & $\delta \mathrm{D}$ plant waxes & Tierney and deMenocal (2013) \\
\hline 6 & Horn of Africa & ${ }^{87} \mathrm{Sr} /{ }^{86} \mathrm{Sr}$ & Jung et al. (2004) \\
\hline $7 a$ & Lake Tana & Ti concentration & Marshall et al. (2011) \\
\hline $7 \mathrm{~b}$ & Lake Tana & $\delta \mathrm{D}$ plant waxes & Costa et al. (2014) \\
\hline 8 & Lake Turkana & Palaeo-shorelines & Garcin et al. (2012) \\
\hline 9 & Lake Victoria & Diatoms & Stager et al. (2003) \\
\hline
\end{tabular}

Blue Nile Rivers to the main Nile flow is similar, and we will therefore consider the inputs from both streams as one component, the Ethiopian Highlands source. The contribution from both sources to the Mediterranean Basin was quantified using end-member mixing models (Box et al., 2011; Blanchet et al., 2013). These modelling approaches allowed to estimate uncertainties and therefore to assess the significance of the changes observed (more details regarding uncertainties can be found in Box et al., 2011 and Blanchet et al., 2013).

In order to account for changes in palaeo-humidity and moisture origin in the northeastern Mediterranean region, we use the palaeo-salinity record from Arz et al. (2003) obtained from sediment cores in the Red Sea. Changes in palaeo-salinity were reconstructed by correcting the stable oxygen isotope record derived from planktonic foraminifera $\left(\delta^{18} \mathrm{O}\right)$ for changes in sea surface temperatures (SST) using the alkenone-based Uk'37 proxy. For a review on uncertainties associated with palaeo-salinity reconstructions, see Leduc et al. (2013). In the Red Sea, the changes in sea surface salinity were attributed to changes in the amount of winter rainfall originating from the Mediterranean (Arz et al.,
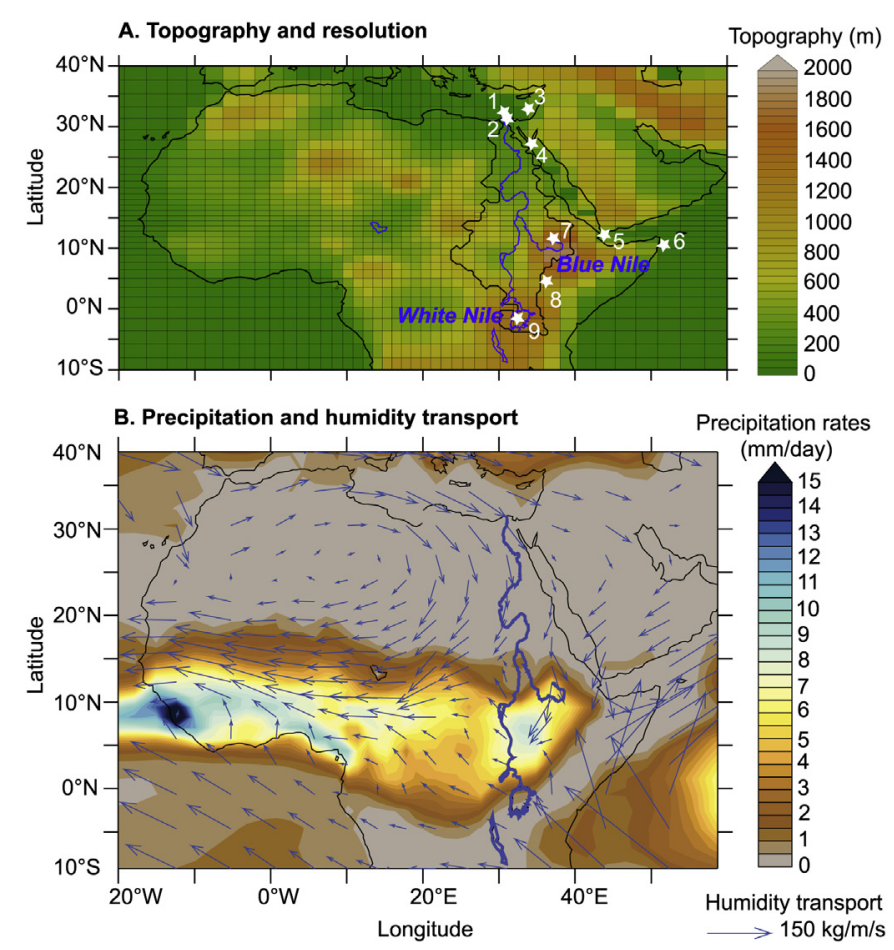

Fig. 2. Model: Methodology and control run. A: LMDZ4 zoomed model grid and topography used in the present-day and mid-Holocene simulations, on which the Nile River and the sites used in the data compilation have been superimposed (for numbering and references, see Table 1). B: Summer (June-July-August) precipitation field (colours) and humidity transport integrated over all the atmospheric layers (vectors) for the pre-industrial control run. (For interpretation of the references to colour in this figure legend, the reader is referred to the web version of this article.) 
2003).

Further south, we use two records north and south off the Horn of Africa. The northernmost one is based on the stable hydrogen isotope $(\delta D)$ record from Tierney and deMenocal (2013) obtained from airborne plant waxes (n-alkanes) deposited in the sediments. The $\delta \mathrm{D}$ composition of plant waxes is influenced by both the changes in the $\delta \mathrm{D}$ of precipitation, which is related to the provenance of the rainfall, and the changes in the amount of precipitation, with enriched isotopic values corresponding to drier conditions. This proxy is here used as an indicator for changes in palaeo-humidity and moisture transport from the Indian Ocean to the Horn of Africa (Tierney and deMenocal, 2013). The southernmost record is the ${ }^{87} \mathrm{Sr} /{ }^{86} \mathrm{Sr}$ record from Jung et al. (2004) obtained from the terrigenous fraction of marine sediments and used as a tracer for weathering intensity on the Horn of Africa. The radiogenic ${ }^{87} \mathrm{Sr}$ isotope being more mobile than the stable ${ }^{86} \mathrm{Sr}$ isotope, enhanced chemical weathering leads to a lower ${ }^{87} \mathrm{Sr} /{ }^{86} \mathrm{Sr}$ ratio. As weathering is stimulated by more humid conditions, a decrease in ${ }^{87} \mathrm{Sr} /{ }^{86} \mathrm{Sr}$ can be related to more humid conditions in the hinterland (in absence of a change in the provenance of the sediments).

All continental records originate from lake sediments except the record of sediment accumulation on the Nile Delta computed by Marriner et al. (2012), which was obtained using an extensive dataset of ${ }^{14} \mathrm{C}$ dates from various locations on the delta that track the evolution of the Nile delta hydro-geomorphology. The rate of sediment accumulation published in Marriner et al. (2012) is taken as a proxy for the main Nile River runoff. The reconstruction of the Blue/White Nile dynamics obtained from marine sediments are then compared to lake sedimentary records obtained at Lakes Tana and Victoria, respectively located at the source of the Blue Nile and White Nile. The palaeo-humidity at Lake Tana was explored using two sedimentary records: i) the titanium (Ti) concentration was used by Marshall et al. (2011) to reconstruct erosion rates related to the amount of rainfall; ii) the $\delta \mathrm{D}$ of plant waxes was interpreted by Costa et al. (2014) as a tracer for the precipitation source. Due to the volcanic nature of the catchment area at Lake Tana, Ti content is a good indicator for autochtonous terrigenous input, especially when it varies synchronously with changes in the magnetic mineralogy (volcanic rocks being enriched in Ti-magnetite) (Marshall et al., 2011). However, it should be mentioned that variations in the Ti content can also arise from dilution by other elements or from non-linear relationships between XRF-counts and actual Ti contents, which are both shown on Fig. 3e (cf. Weltje and Tjallingii, 2008; for a review on XRF-based elemental reconstructions). As already mentioned, the $\delta \mathrm{D}$ of plant waxes is a mixed signal of changes in the amount and provenance of the rainfall, which are difficult to disentangle. The interpretation of the $\delta \mathrm{D}$ record from Lake Tana as an indicator of changes in moisture source is based on the comparison with the Ti-content record from Marshall et al. (2011) (Costa et al., 2014) and, for the reasons stated above, should be taken with caution. The statistical analysis of assemblages of fossil freshwater diatoms from Lake Victoria allowed Stager et al. (2003) to explore both the changes in the amount and seasonality of rainfall during the Holocene. The clustering of diatoms species using multivariate data analysis performed by Stager et al. (2003) allows to reconstruct the ecological conditions in Lake Victoria, which are related to the changes in lake level and mixing/stratification, both being controlled by climatic changes (precipitation rates, seasonality, wind strength). The changes in lake level at Lake Turkana obtained by Garcin et al. (2012) using ${ }^{14} \mathrm{C}$ dating of palaeo-shorelines provide crucial insights on palaeo-humidity dynamics for lake systems that were probably contributing to the White Nile runoff during the AHP, when Lake Turkana overflowed to the North, i.e. into the White Nile catchment.

\subsection{Modelling experiment framework}

We used the LMDZ4 atmosphere general circulation model, which has a stretchable grid (Li and Conil, 2003), to carry out a present-day control and a mid-Holocene global simulation zoomed on the Lake Chad region (Contoux et al., 2013). The model is based on a finite-difference discretization of the equations of fluid dynamics with conservation of enstrophy (Hourdin et al., 2006). Parameterization of convection follows the Emanuel scheme (Emanuel, 1993). No data assimilation was done, implying that the model simulation output is fully independent of the palaeoreconstructions described in chapter 3.1. The initial resolution of the model is $3.75^{\circ}$ in longitude by $2.5^{\circ}$ in latitude with 19 vertical layers. Because we use the zooming capability of the model, the horizontal resolution is 3 times finer over the central grid of the zoom $(\sim 100 \mathrm{~km})$ and progressively declines (Fig. 2a). This finer resolution over North and Central Africa allows a much better representation of topography than in other global climate models, a feature important when investigating the response of the regional hydrological cycle to palaeoclimatic conditions in the African Rift region. A full description of the LMDZ4 model can be found in Hourdin et al. (2006). For the present-day control simulation (0 ka, Fig. 2b), SSTs are forced with the climatological mean value for 1988-2007 from the AMIP 2 dataset. Greenhouse gases, solar constant and orbital parameters are set to pre-industrial values (i.e., $\mathrm{CO}_{2}$ at $280 \mathrm{ppm}$ ) as required by CMIP5/PMIP3. For the midHolocene simulation, SST and sea-ice are forced with midHolocene SST anomalies previously calculated through a coupled mid-Holocene simulation with IPSL-CM5A (Kageyama et al., 2013), which compares favourably with independent mid-Holocene palaeo-SST reconstructions (Contoux et al., 2013). Orbital parameters are prescribed to $6 \mathrm{ka}$ values, and $\mathrm{CO}_{2}$ is set to $280 \mathrm{ppm}$, following PMIP3 guidelines. Ice sheets and topography are the same as for the control simulation. Vegetation boundary condition for the mid-Holocene is calculated with BIOME4 (Kaplan et al., 2003), using the climatology from a first mid-Holocene simulation forced with control vegetation. A more complete description of this mid-Holocene and control LMDZ4 simulations can be found in Contoux et al. (2013).

The boreal summer precipitation field as simulated in the present-day control run matches well with modern observation (Figs. 1 and 2; see also Contoux et al., 2013). In particular, precipitation maxima are clustered above West Africa and at the southern edge of the Ethiopian Highlands (Fig. 2b). The high-resolution grid and topography provides a rainfall pattern over East Africa that is much more detailed than those simulated using the same atmospheric model without the zoom on Africa (Hourdin et al., 2006; Marzin and Braconnot, 2009), even though the eastern African high precipitation zone is slightly shifted southward compared to observations (Fig. 2b). The simulated humidity transport also captures the dominance of the Mediterranean source for moisture transported through the Arabian Peninsula towards northeastern Africa (Viste and Sorteberg, 2013), which ultimately precipitates above the Ethiopian Highlands (Fig. 2b). The intense moisture transport towards Africa originating from the Indian Ocean is mostly deflected towards the southern Arabian peninsula, with only a small proportion reaching the Nile catchment and contributing to rainfall there (Fig. 2b).

\section{Results}

\subsection{Proxy-data}

Using records from the Nile Valley (Fig. 3), we explore the temporal changes in the overall Nile runoff. In accordance with 

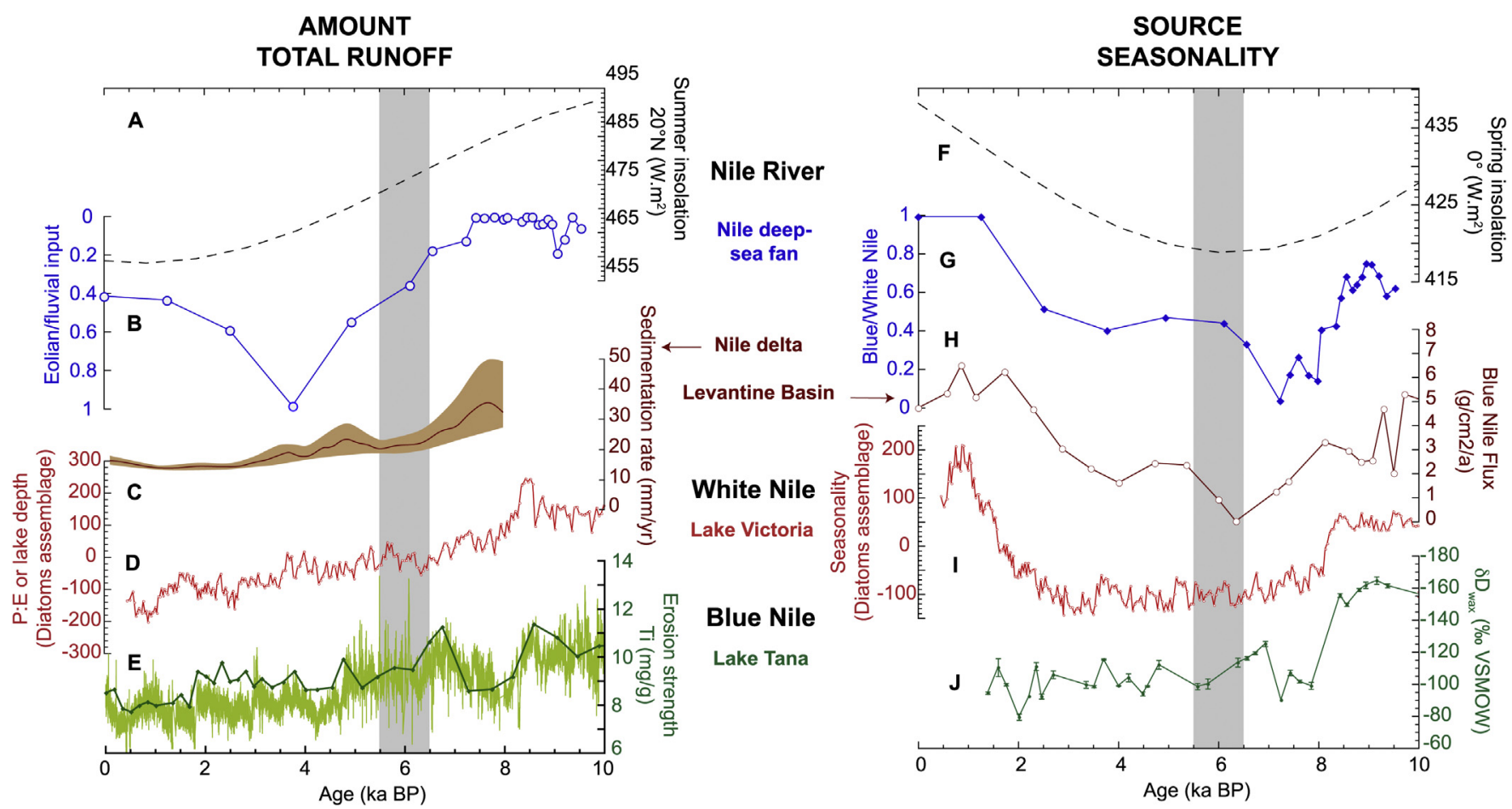

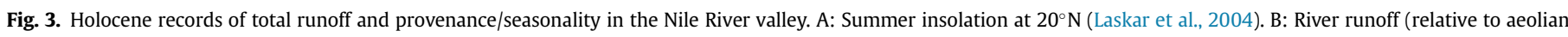

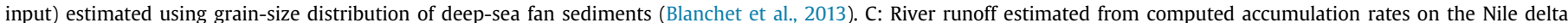

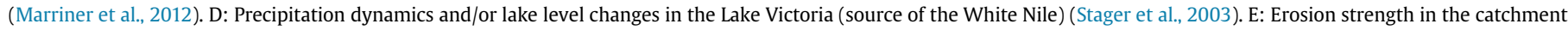

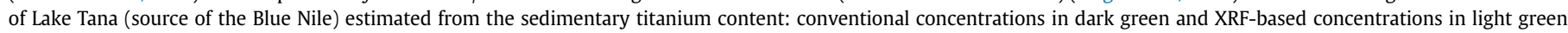

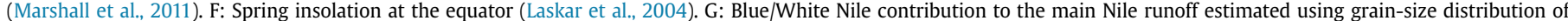

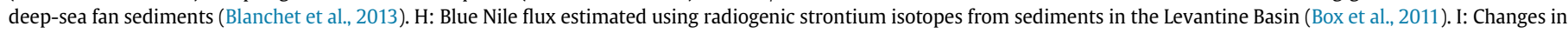

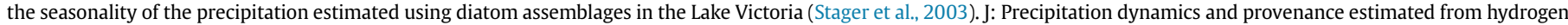

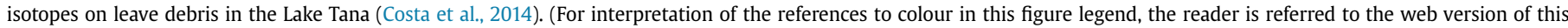
article.)

other proxy-records (Revel et al., 2010; Flaux et al., 2013; Weldeab et al., 2014), the datasets presented on Fig. 3 depict a gradual decrease throughout the Holocene, which follows the changes in boreal summer insolation at the tropics (Stager et al., 2003; Marshall et al., 2011; Marriner et al., 2012; Blanchet et al., 2013).

The changes in the relative contribution from both sources to the main Nile exhibit a different pattern (Fig. 3). The early Holocene interval $(10-8.5 \mathrm{ka})$ is characterized by a large contribution from the Blue Nile to the main Nile runoff and high Blue Nile fluxes (Fig. $3 g, h$ ). This interval of large Blue Nile contribution is also characterized by high sedimentation rates and thick flood-derived layers on the Nile deep-sea fan (Revel et al., 2010; Blanchet et al., 2013, 2014). This suggests the occurrence of exceptional floods originating from the Blue Nile, which is corroborated by the description of massive flood deposits in the former Nile River bed (reaching up to 5-m height) during a period referred to as the "Wild Nile" (Butzer, 1980). A rapid switch is observed at ca. 8.5-7 ka towards a lower Blue Nile contribution and a higher White Nile contribution (Fig. $3 \mathrm{~g}, \mathrm{~h}$ ), which lasts until $\sim 6 \mathrm{ka}$. The Blue Nile contribution then steadily increased to reach a maximum at ca. $1 \mathrm{ka}$. This trend was also reported in radiogenic strontium and lead isotope records from the northeastern (Krom et al., 2002) and northwestern Nile Delta (Véron et al., 2013). These changes in the Blue/White Niles contributions to the main Nile follow the variations in spring/autumn insolation at the Equator (Fig. 3f) and are not mirrored in the changes of the overall Nile runoff (Fig. 3c).

In order to investigate the precipitation dynamics at the two main sources of the Nile River, we use records from Lake Victoria (Fig. 3d, i) and Lake Tana (Fig. 3e, j) (Stager et al., 2003; Marshall et al., 2011; Costa et al., 2014). At the source of the White Nile, the changes in lake level are related to changes in precipitation rates and follow changes in the boreal summer insolation (Fig. 3a, d), while the changes in seasonality follow changes in boreal spring insolation (Fig. 3f, i). At the source of the Blue Nile, the sedimentary Ti content mostly reflects changes in terrigenous input to Lake Tana from its catchment and exhibit large millennial-scale changes superimposed on a long-term decrease. Intervals of lower Ti contents are observed at $8.5-7 \mathrm{ka}$ and after $4.5 \mathrm{ka}$, which are also seen in the record of past precipitation of Costa et al. (2014) (Fig. 3j). The major decrease in plant waxes $\delta \mathrm{D}$ at $8.5-8 \mathrm{ka}$ was interpreted as a change in the provenance of precipitation, which was assumed to originate from the Atlantic Ocean (through the African Monsoon) before $8.5 \mathrm{ka}$ BP and from the Indian Ocean (through the East African Monsoon) afterwards (Costa et al., 2014).

\subsection{Model results}

Simulated mid-Holocene precipitation anomalies over Central and East Africa depict a globally higher summer precipitation rate during the mid-Holocene, due to a northward shift of the rainfall belt (Fig. 4a). The enhanced African and Indian monsoons during the mid-Holocene (Marzin and Braconnot, 2009) lead to a northward ITCZ shift, combined to an eastward shift of the Congo Air Boundary. Consequently, moisture convergence occurs north of the Ethiopian Highlands, creating a negative anomaly of precipitation over the Blue Nile basin. Meanwhile, higher precipitation rates are simulated above the White Nile catchment and above the southern Red Sea during summer months, due to enhanced convection above 

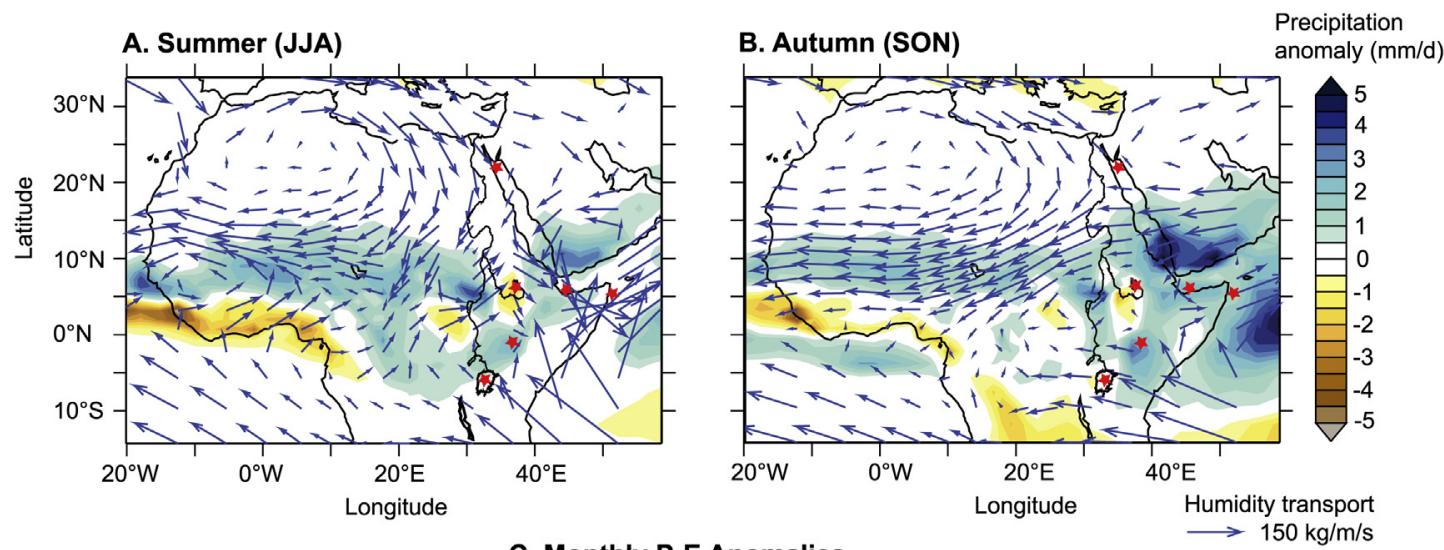

C. Monthly P-E Anomalies

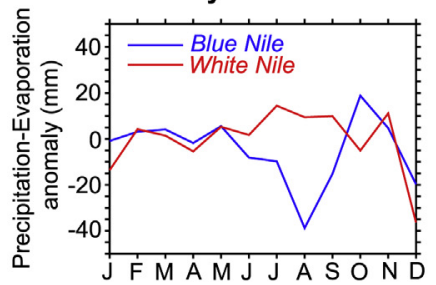

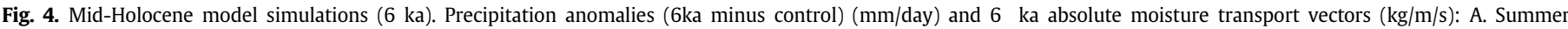

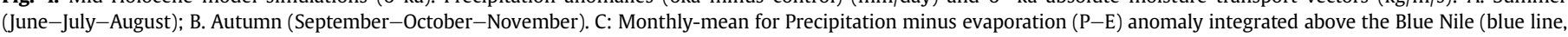

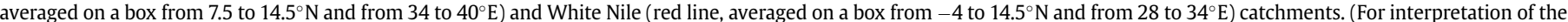
references to colour in this figure legend, the reader is referred to the web version of this article.)

the Congo Air Boundary. During the autumn months, more rainfall is also simulated north of Khartoum in the modern desert Nile. Precipitation minus evaporation $(\mathrm{P}-\mathrm{E})$ anomalies show patterns similar to the precipitation anomaly, with a significant negative anomaly for the Blue Nile basin in the summer months (Fig. 4c).

Simulated moisture transport indicates that monsoonassociated southeasterly winds originating from the Atlantic are increased over the continent at $6 \mathrm{ka}$ along with a northward displacement of the moisture atmospheric pathways (Figs. 2b and $4 a)$. An increase in strength of the northwesterly winds and its associated moisture transport from the Mediterranean is also depicted in summer, but is deflected towards the Sahel and southern Sahara regions (Figs. $2 \mathrm{~b}$ and $4 \mathrm{a}$ ). Above the Ethiopian Highlands, the dominant northern origin of moisture as observed and simulated for the present-day is no longer traceable and moisture convergence occurs north and east of the Ethiopian Highlands, leaving the region in a rain shadow (Fig. 4a).

During the autumn, large positive precipitation anomalies are depicted over the Southern Red Sea, southern Arabia and in the Indian Ocean, partially reaching the northern part of the Blue Nile basin, over which the negative precipitation anomaly is shifted southward (Fig. 4b). This is due to increased easterlies transporting humidity from the Indian Ocean to North Africa with the exception of the Horn of Africa, which is under the influence of the Indian monsoonal cell (Fig. 4b). This results in positive P-E anomaly over the northern Blue Nile basin in autumn (Fig. 4c). In contrast, the $\mathrm{P}-\mathrm{E}$ anomaly in the White Nile Basin is positive from May to September.

\section{Discussion}

\subsection{Precipitation dynamics in the Nile catchment and source contribution}

As stated in part 4.1, the proxy-records from the Mediterranean Basin exhibit large variations in the contribution of the Blue and
White Niles to the main Nile runoff throughout the Holocene, which are not mirrored in the changes in the overall Nile runoff (Fig. 3) (Krom et al., 2002; Box et al., 2011; Blanchet et al., 2013). Especially, the large switch between 8.5 and 5 ka from a Blue Niledominated to a White Nile-dominated runoff is not accompanied by a synchronous decrease in the overall Nile runoff (Fig. 3g, h). In order to maintain the overall Nile runoff to a near-similar level, the decrease in the Blue Nile runoff has likely been balanced by an increase in the White Nile runoff.

Several mechanisms have been proposed to explain this observation. Blanchet et al. (2013) proposed that a shift in the seasonal distribution of precipitation towards the autumn equinox stimulated a stronger White Nile runoff during the mid-Holocene. Krom et al. (2002) and Box et al. (2011) attributed the lower Blue Nile runoff during the Mid-Holocene to the development of an extensive vegetation cover on the Ethiopian Highlands that prevented erosion, with precipitation rates remaining high.

In our mid-Holocene simulation, the White Nile catchment receives a sustained amount of rainfall both in summer and autumn (Fig. 4). Furthermore, the mid-Holocene White Nile drainage area included several lakes such as Lake Turkana (Garcin et al., 2012). This lake was contributing a significant amount to the White Nile runoff during the AHP but is no longer overflowing into the modern White Nile catchment. Our simulation indeed depicts a sustained positive precipitation anomaly at the location of Lake Turkana (Fig. 4). We therefore propose that the higher White Nile contribution to the main Nile runoff during the mid-Holocene likely reflects higher precipitation rates in Equatorial areas and the connection to past tributaries like Lake Turkana.

In contrast, the model simulates reduced precipitation over the Ethiopian Highlands during summer at $6 \mathrm{ka}$, but slightly enhanced rainfall in the northern part of the Ethiopian Highlands during the autumn (Fig. 4). The P-E was also reduced in summer and higher in autumn at 6 ka (Fig. 4c). A negative precipitation anomaly over the Blue Nile basin during the mid-Holocene has also been simulated in Bosmans et al. (2012), using the high-resolution general circulation 
model EC_Earth. The P-E was also reduced in summer and higher in autumn at $6 \mathrm{ka}$ (Fig. 4c). This summer precipitation decrease over the Blue Nile basin supports the hypothesis of Blanchet et al. (2013) that the decrease in the Blue Nile contribution was related to the occurrence of the peak of precipitation in autumn. Furthermore, the hypothesis of Krom et al. (2002) and Box et al. (2011) that the reduced Blue Nile contribution resulted from a decrease in erosion due to extensive vegetation cover on the Ethiopian Highlands is not supported by the increase in erosion rates observed by Marshall et al. (2011) at the Lake Tana. We speculate that the erosion rates at Lake Tana were not linearly correlated to precipitation rates and that a more intense erosion might as well be related to higher land exposure (due to a reduction in vegetation cover). Further processes that could explain the nonlinearity between high erosion rates and low Blue Nile fluxes involve river sediment transport capability, erosion potential in source areas (Zhao et al., 2011) as well as sediment trapping in downstream regions such as in the Gezira region at the confluence of the White and Blue Niles (Williams, 2009).

\subsection{Regional rainfall dynamics and atmospheric mechanisms}

When compiling proxy-records from NE Africa, a striking variability in both the spatial and temporal distribution of rainfall is observed (Fig. 5). We plotted records from the Horn of Africa (Jung et al., 2004; Tierney and deMenocal, 2013), from the northern Red Sea (Arz et al., 2003) and from the Lake Tana (Marshall et al., 2011; Costa et al., 2014) and Lake Turkana (Garcin et al., 2012), which together provide a synoptic view on regional precipitation changes. Between ca. 10 and $8 \mathrm{kyr}$ BP, all sites recorded significantly more humid conditions. The transition towards more arid conditions occurred with a different timing and pace at the various locations: between 6 and $4 \mathrm{kyr}$ BP on the Horn of Africa and at Lake Turkana, between 7 and 6 kyr BP in the Red Sea and around 8 kyr BP at Lake Tana. Taken together, these records depict a complex picture, which so far hindered our understanding of the climatic mechanisms controlling the changes in precipitation and runoff in northeastern Africa. We use here the model output to place each record in a larger regional frame and explore the influence of changes in

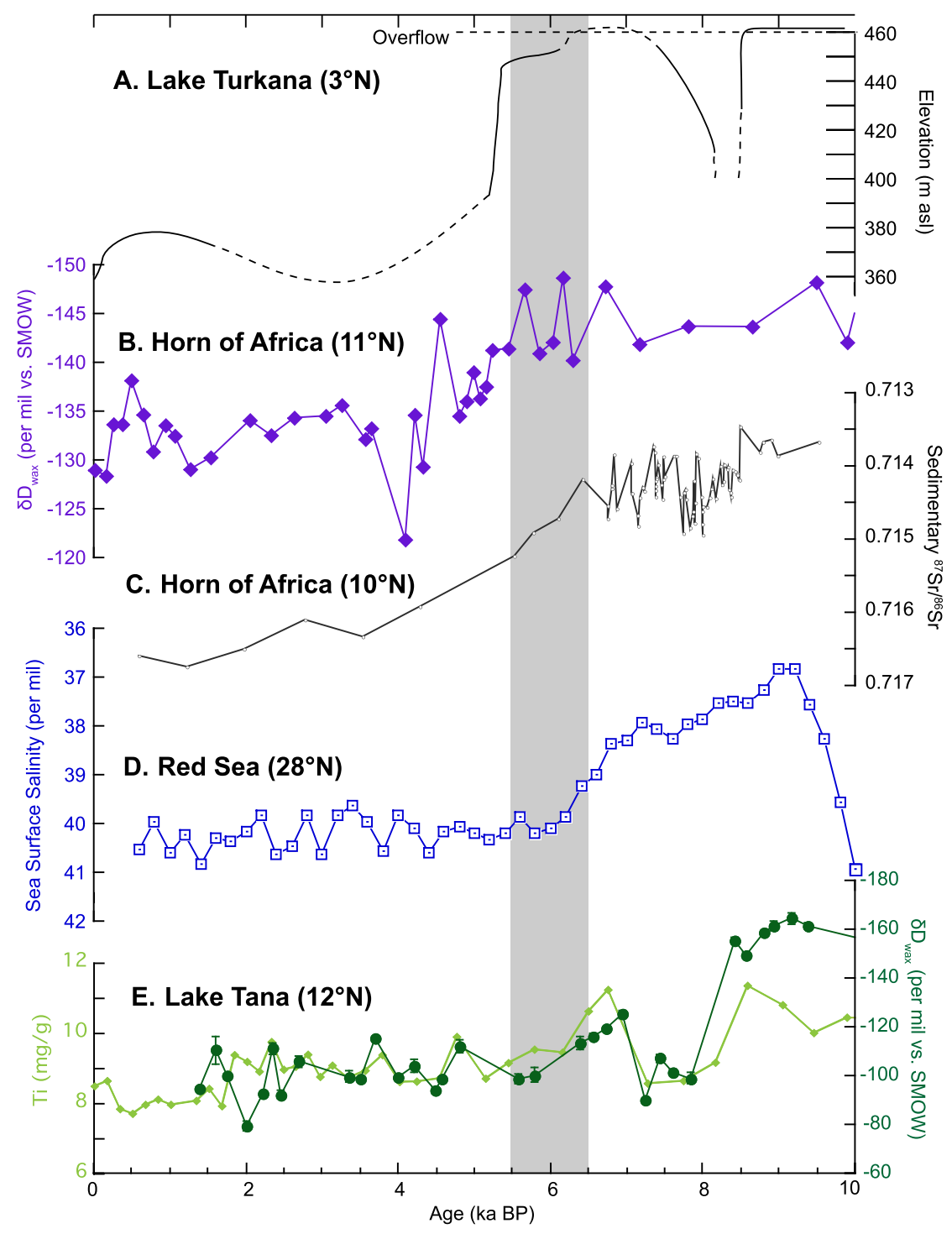

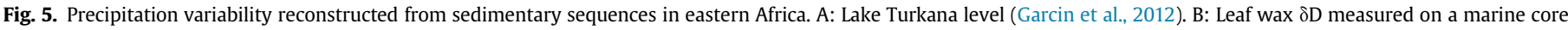

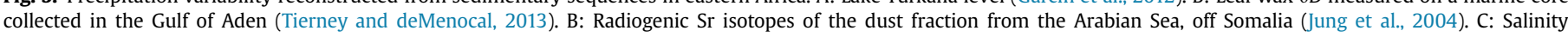

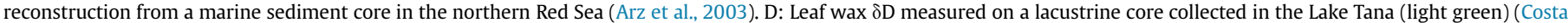

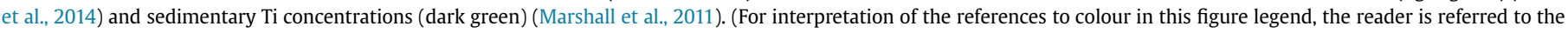
web version of this article.) 
moisture sources on the distribution of rainfall in eastern Africa.

At present, the Ethiopian Highlands are a strong convergence zone during the boreal summer (e.g. Korecha and Barnston, 2007). Moisture brought to the region originates mostly from the Mediterranean region, and to a lesser extent from the Indian Ocean and the Gulf of Guinea (the latter being the smallest contributor) (Viste and Sorteberg, 2013, Fig. 1). In our simulation, the southwesterly monsoon winds were enhanced at $6 \mathrm{ka}$ and humidity transport from the Gulf of Guinea to the Ethiopian Highlands was also enhanced (Fig. 4a), while the moisture transport from the Indian Ocean and Northern sources was reduced (compare Figs. 1 and 4a). Moisture convergence occurred over the southern Red Sea and Arabian Peninsula in summer and autumn, which might have largely accounted for the mid-Holocene rainfall maximum recorded over the Horn of Africa (Figs. 4 and 5b,c) (Jung et al., 2004; Tierney and deMenocal, 2013). Further to the North, however, an increase in the salinity reconstructed from a marine sediment core from the northern Red Sea at $7 \mathrm{ka}$ is best explained by a drastic reduction in moisture transport from the Mediterranean region towards the northern Red Sea (Fig. 5d; Arz et al., 2003). According to our model-data comparison, moisture transport from the Mediterranean Basin appears to have largely contributed to early-to mid-Holocene humid conditions in NE Africa. This northern moisture source might have been underestimated in reconstructions based on isotopic records from NE Africa, which mainly considered wetter conditions associated with a northward displacement of the ITCZ (Tierney and deMenocal, 2013; Costa et al., 2014).

\section{Conclusions and outlook}

In this article, we compare key proxy-records of changes in humidity within the Nile River catchment and NE Africa to a midHolocene simulation from a global atmospheric model to explore the rainfall dynamics over eastern Africa during the Holocene. The record compilation allows to explore the pace and timing of changes in overall Nile Runoff and contribution from its two main sources, the Blue and the White Nile. It showed that the source contribution to the main Nile runoff largely varied during the Holocene, with a lower Blue Nile contribution at the mid-Holocene (Krom et al., 2002; Box et al., 2011; Blanchet et al., 2013). This observation challenges the view of enhanced rainfall in the northern tropics and especially at the Blue Nile source during the mid-Holocene (Chalié and Gasse, 2002; Marshall et al., 2011; Costa et al., 2014). The changes in the source contribution to the main Nile runoff follow the changes in the autumn/spring insolation, whereas the changes in the overall Nile runoff follow the gradual decrease in summer insolation.

In order to understand the role of precipitation changes on the runoff dynamics, we used a high-resolution atmospheric model zoomed above Africa, which provides accurate simulations of present-day precipitation rates and moisture sources over the region. The model simulation at 6 ka shows that the intensification of the African monsoon led to a northward shift of the ITCZ and an eastward shift of the Congo Air Boundary. As a result, moisture convergence occurred North of the Ethiopian Highlands, which remained in a rain shadow and exhibit a negative summer precipitation anomaly. By contrast, the White Nile catchment received more precipitation both in summer and autumn and its watershed was extended, due to overflowing lakes. These results therefore suggest that the reduction in Blue Nile runoff was balanced by a higher White Nile runoff, which led to a sustained overall Nile River runoff. We find that both seasonal distribution and source of moisture may have exerted a key role on rainfall dynamics.

We also compiled regional palaeo-humidity records from NE Africa, which show contrasting pace and timing of the wet/dry transition during the AHP termination. The model output offers a synoptic view on regional rainfall dynamics that helped to reconcile these various regional proxy-records. In particular, we found that the moisture transport from the Mediterranean region might have played a significant role in modulating the rainfall over the Ethiopian highlands and might have been underestimated in interpreting palaeo-humidity records from NE Africa. Overall our results highlight the importance of using high-resolution or zoomed models to track the changes in the hydrological cycle in regions where the topography is complex, leading to large regional variations.

\section{Acknowledgements}

CLB was funded through a personal grant (project BL11121/1) by the German Science Foundation (DFG). CC is funded by the Labex OT-Med through the project CHAD-UNITE. This work is a contribution to the Labex OT-Med (ANR-11-LABEX-0061) funded by the " Investissements d'Avenir », French Government project of the French National Research Agency (ANR) through the $A^{*}$ Midex project (ANR-11-IDEX-0001-02). GL thanks Marie-Alexandrine Sicre and the PaleoMex/MISTRALS program for financial support. Comments made by Jamie Woodward, Eduardo Garzanti and an anonymous reviewer significantly improved the quality of the manuscript.

\section{References}

Arz, H., Lamy, F., Pätzold, J., Müller, P.J., Prins, M., 2003. Mediterranean moisture source for an early-Holocene humid period in the Northern Red Sea. Science 300, 118-121.

Blanchet, C.L., Tjallingii, R., Frank, M., Lorenzen, J., Reitz, A., Brown, K., Feseker, T., Brueckmann, W., 2013. High- and low-latitude forcing of the Nile River regime during the Holocene inferred from laminated sediments of the Nile deep-sea fan. Earth Planet. Sci. Lett. 364, 98-110.

Blanchet, C.L., Frank, M., Schouten, S., 2014. Asynchronous changes in vegetation, runoff and erosion in the Nile river watershed during the Holocene. PLoS ONE 9 (12), e115958. http://dx.doi.org/10.1371/journal.pone.0115958.

Braconnot, P., Otto-Bliesner, B., Harrison, S., Joussaume, S., Pe- terchmitt, J.-Y., AbeOuchi, A., Crucifix, M., Driesschaert, E., Fichefet, Th, Hewitt, C.D., Kageyama, M., Kitoh, A., Laîné, A., Loutre, M.-F., Marti, O., Merkel, U., Ramstein, G., Valdes, P., Weber, S.L., Yu, Y., Zhao, Y., 2007. Results of PMIP2 coupled simulations of the Mid-Holocene and Last Glacial Maximum - Part 1: experiments and large-scale features. Clim. Past. 3, 261-277. http://dx.doi.org/10.5194/cp-3-261-2007.

Bosmans, J.H.C., Driifhout, S.S., Tuenter, E., Lourens, L.J., Hilgen, F.J., Weber, S.L., 2012 Monsoonal response to mid-holocene orbital forcing in a high resolution GCM. Clim. Past 8, 723-740.

Box, M., Krom, M., Cliff, R., Bar-Matthews, M., Almogi-Labin, A., Ayalon, A., Paterne, M., 2011. Response of the Nile and its catchment to millennial-scale climatic change since the LGM from $\mathrm{Sr}$ isotopes and major elements of East Mediterranean sediments. Quat. Sci. Rev. 30, 431-442.

Butzer, K.W., 1980. Pleistocene history of the Nile Valley in Egypt and Lower Nubia. In: Williams, M.A.J., Faure, H. (Eds.), The Sahara and the Nile. Quaternary Environments and Prehistoric Occupation in Northern Africa. AA. Balkema, Rotterdam, pp. 253-280.

Chalié, F., Gasse, F., 2002. Late Glacial-Holocene diatom record of water chemistry and lake level change from the tropical East African Rift Lake Abiyata (Ethiopia). Palaeogeogr. Palaeoclimatol. Palaeoecol. 187, 259-283.

Claussen, M., Kubatzki, C., Brovkin, V., Ganopolski, A., Hoelzmann, P. Pachur H.J. 1999. Simulation of an abrupt change in Saharan vegetation in the mid-Holocene. Geophys. Res. Lett. 26, 2037-2040.

Contoux, C., Jost, A., Ramstein, G., Sepulchre, P., Krinner, G., Schuster, M., 2013. Megalake Chad impact on climate and vegetation during the Late Pliocene and the Mid-Holocene. Clim. Past 9, 1417-1430.

Costa, K., Russel, J., Konecky, B., Lamb, H., 2014. Isotopic reconstruction of the African humid period and Congo air boundary at Lake Tana. Ethiop. Quat. Sci. Rev. 83, 58-67.

Davis, B.A.S., Brewer, S., 2009. Orbital forcing and role of the lati- tudinal insolation/ temperature gradient. Clim. Dynam. 32, 143-165. http://dx.doi.org/10.1007/ s00382-008-0480-9.

Drake, N., Blench, R., Armitage, S., Bristow, C., White, K., 2011. Ancient watercourses and biogeography of the Sahara explain the peopling of the desert. Proc. Natl. Acad. Sci. U. S. A. 108, 458-462.

Emanuel, K.A., 1993. A cumulus representation based on the episodic mixing model: the importance of mixing and microphysics in predicting humidity. AMS Meteorol. Monogr. 24, 185-192. 
Flaux, C., Claude, C., Marriner, N., Morhange, C., 2013. A 7,500-yr strontium isotope record from the northwestern Nile Delta (Maryut Lagoon, Egypt). Quat. Sci. Rev. $78,22-33$.

Fleitmann, D., Burns, S.J., Mudelsee, M., Neff, U., Kramers, J., Mangini, A., Matter, A., 2003. Holocene forcing of the Indian Monsoon recorded in a stalagmite from southern Oman. Science 300, 1737-1739.

Garcin, Y., Melnick, D., Strecker, M.R., Olago, D., Tiercelin, J.J., 2012. East African midHolocene wet-dry transition recorded in palaeo-shorelines of Lake Turkana, northern Kenya Rift. Earth Planet. Sci. Lett. 331-332, 322-334.

Gasse, F., 2000. Hydrological changes in the African tropics since the Last Glacial Maximum. Quat. Sci. Rev. 19, 189-211.

Hourdin, F., Musat, I., Bony, S., Braconnot, P., Codron, F., Dufresne, J.-F., Fairhead, L., Filiberti, M-A. Friedlingstein, P. Grandpeix, J-Y, Levan, P. Li, Z-X., Lott, F. 2006. The LMDZ4 general circulation model: climate performance and sensitivity to parametrized physics with emphasis on tropical convection. Clim. Dyn. 27, 787-813.

Howell, P., Lock, M., Cobb, S. (Eds.), 1988. The Jonglei Canal: Impact and Opportunity. Cambridge University Press, Cambridge.

Jolly, D., Harrison, S.P., Damnati, B., Bonnefille, R., 1998. Simulated climate and biomes of Africa during the Late Quaternary: comparison with pollen and lake status data. Quat. Sci. Rev. 17, 629-657.

Jung, S.J.A., Davies, G.R., Ganssen, G.M., Kroon, D., 2004. Stepwise Holocene aridification in NE Africa deduced from dust-borne radiogenic isotope records. Earth Planet. Sci. Lett. 221, 27-37.

Kageyama, M., Braconnot, P., Bopp, L., Caubel, A., Foujols, M.-A., Guilyardi, E., Khodri, M., Lloyd, J., Lombard, F., Mariotti, V., Marti, O., Roy, T., Woillez, M.-N., 2013. Mid-Holocene and Last Glacial Maximum climate simulations with the IPSL model, Part 1: comparing IPSL CM5A to IPSL CM4. Clim. Dyn. 40, 2447-2468. http://dx.doi.org/10.1007/s00382-012-1488-8.

Kaplan, J.O., Bigelow, N.H., Prentice, I.C., Harrison, S.P., Bartlein, P.J., Christensen, T.R., Cramer, W., Matveyeva, N.V., McGuire, A.D., Murray, D.F., Razzhivin, V.Y., Smith, B., Walker, D.A., Anderson, P.M., Andreev, A.A., Brubaker, L.B., Edwards, M.E., Lozhkin, A.V., 2003. Climate change and Arctic ecosystems: 2. modeling, paleodata-model comparisons, and future projections. J. Geophys. Res. 108, 8171. http://dx.doi.org/10.1029/2002JD002559.

Korecha, D., Barnston, A.G., 2007. Predictability of June-September rainfall in Ethiopia. Mon. Weather Rev. 135, 628-650. http://dx.doi.org/10.1175/ MWR3304.1.

Krom, M.D., Stanley, J.D., Cliff, R.A., Woodward, J.C., 2002. Nile River sediment fluctuation over the past $7000 \mathrm{yr}$ and their role in sapropel development. Geology $30,71-74$

Kröpelin, S., Verschuren, D.A.-M.L., Eggermont, H., Coquyt, C., Francus, P., Cazet, J.P., Fagot, M., Rumes, B., Russel, J.M., Darius, F., Conley, D.J., Schuster, M., von Suchodoletz, H., Engstrom, D.R., 2008. Climate-driven ecosystem succession in the Sahara: the past 6000 years. Science 320, 765-768.

Kuper, R., Kröpelin, S., 2006. Climate-controlled Holocene occupation in the Sahara: motor of Africa's evolution. Science 313, 803-807.

Laskar, J., Robutel, P., Joutel, F., Gastineau, M., Correia, A.C.M., Levrard, B., 2004. A long term numerical solution for the insolation quantities of the Earth. Astronomy Astrophysics 428, 261-285.

Leduc, G., Sachs, J.P., Kawka, O.E., Schneider, R.R., 2013. Holocene changes in eastern equatorial Atlantic salinity as estimated by water isotopologues. Earth Planet. Sci. Lett. 362, 151-162.

Li, Z.X., Conil, S., 2003. Transient response of an atmospheric GCM to North Atlantic SST anomalies. J. Clim. 16, 3993-3998.

Liu, Z., Wang, Y., Gallimore, R., Gasse, F., Johnson, T., deMenocal, P., Adkins, J., Notaro, M., Prentice, I.C., Kutzbach, J., Jacob, R., Behling, P., Wang, L., Ong, E., 2007. Simulating the transient evolution and abrupt change of Northern Africa atmosphere-ocean-terrestrial ecosystem in the Holocene. Quat. Sci. Rev. 26, 1818-1837.

Macklin, M.G., Woodward, J.C., Welsby, D.A., Duller, G.A., Williams, F.M. Williams, M.A., 2013. Reach-scale river dynamics moderate the impact of rapid Holocene climate change on floodwater farming in the desert Nile. Geology 41 (6), 695-698.

Macklin, M.G., Lewin, J., 2015. The rivers of civilization. Quart. Sci. Rev. 114 $228-244$.

Marriner, N., Flaux, C., Kaniewski, D., Morhange, C., Leduc, G., Moron, V., Chen, Z Gasse, F., Empereur, J.Y., Stanley, J.D., 2012. ITCZ and ENSO-like pacing of Nile delta hydro-geomorphology during the Holocene. Quat. Sci. Rev. 45, 73-84.

Marshall, M.H., Lamb, H.F., Huws, D., Davies, S.J., Bates, R., Bloemendal, J., Boyle, J., Leng, M.J., Umer, M., Bryant, C., 2011. Late Pleistocene and Holocene drought events at Lake Tana, the source of the Blue Nile. Glob. Planet. Change 78, $147-161$.

Marzin, C., Braconnot, P., 2009. Variations of Indian and African monsoons induced by insolation changes at 6 and 9.5 kyr BP. Clim. Dyn. 33, 215-231.

Padoan, M., Garzanti, E., Harlavan, Y., Villa, I.M., 2011. Tracing Nile sediment sources by $\mathrm{Sr}$ and Nd isotope signatures (Uganda, Ethiopia, Sudan). Geochim. Cosmochim. Acta 75, 3627-3644.

Revel, M., Ducassou, E., Grousset, F., Bernasconi, S., Migeon, S., Revillon, S., Mascle, J. Murat, A., Zaragosi, S., Bosch, D., 2010. 100,000 years of African monsoon variability recorded in sediments of the Nile margin. Quat. Sci. Rev. 29, 1342-1362.

Sepulchre, P., Ramstein, G., Fluteau, F., Schuster, M., Tiercelin, J.-J., Brunet, M., 2006 Tectonic uplift and East Africa aridification. Science 313, 1419-1423.

Shanahan, T.M., McKay, N.P., Hughen, K.A., Overpeck, J.T., Otto-Bliesner, B. Heil, C.W., King, J., Scholz, C.A., Peck, J., 2015. The time-transgressive termination of the African Humid Period. Nat. Geosci. 8, 140-144. http://dx.doi.org/ 10.1038/NGEO2329.

Stager, J.C., Cumming, B.F., Meeker, L.D., 2003. A 10,000-year high-resolution diatom record from Pilkington Bay, Lake Victoria, East Africa. Quat. Res. 59, 172-181.

Tierney, J., deMenocal, P., 2013. Abrupt shifts in Horn of Africa hydroclimate since the Last Glacial Maximum. Science 342, 843-846.

Véron, A.J., Flaux, C., Marriner, N., Poirier, A., Rigaud, S., Morhange, C., Empereur, J.Y., 2013. A 6000-yr record of human activites from Alexandria (Egypt). Quat. Sci. Rev. 81, 138-147.

Viste, E., Sorteberg, A., 2013. Moisture transport into the Ethiopian highlands. Int. J Climatol. 33, 249-263.

Weldeab, S., Menke, V., Schmiedl, G., 2014. The pace of the African monsoon evolution during the Holocene. Geophys. Res. Lett. 41, 1724-1731.

Weltje, G.J., Tjallingii, R., 2008. Calibration of XRF core scanners for quantitative geochemical logging of sediment cores: theory and application. Earth Planet. Sci. Lett. 274, 423-438.

Williams, M.A.J., Adamson, D.A., Abdulla, H.H., 1982. Landforms and soils of the Gerzira: a Quaternary legacy of the Blue and White Nile rivers. In Williams, M.A.J., Adamson, D.A. (Eds.), A Land between Two Niles: Quaternary Geology and Biology of the Central Sudan. A.A. Balkema, Rotterdam, pp. 111-142.

Williams, M.A.J., 2009. Late Pleistocene and Holocene environments in the Nile basin. Glob. Planet. Change 69, 1-15.

Woodward, J.C., Macklin, M.G., Krom, M.D., Williams, M.A.J., 2007. The Nile: evolution, Quaternary river environments and material fluxes. In: Gupta, A. (Ed.) Large Rivers: Geomorphology and Management. John Wiley \& Sons, Ltd, pp. 261-292.

Zhao, Y., Liu, Z., Colin, C., Paterne, M., Siani, G., Cheng, X., Duchamp-Alphonse, S., Xie, X., 2011. Variations of the Nile suspended discharges during the last 1.75 Myr. Paleogeogr. Paleoclimatol. Paleoecol. 311, 230-241. 